\title{
Geospatial analysis of water uses and potential conflicts in the microregion of Ceres, Goiás, Brazil
}

\author{
Análise geoespacial dos usos da água e os conflitos \\ potenciais na microrregião de Ceres, Goiás, Brasil
}

Cristiane Gomes Barreto ${ }^{a}$

Renato Arthur Franco Rodrigues ${ }^{b}$

José Augusto Leitão Drummond ${ }^{c}$

${ }^{a}$ Doutora em Desenvolvimento Sustentável, professora adjunta do Centro de Desenvolvimento Sustentável da Universidade de Brasília, Brasilia, DF, Brasil.

E-mail: crisgbarreto@gmail.com

${ }^{b}$ Mestrando do Programa de Pós-graduação do Centro de Desenvolvimento Sustentável da Universidade de Brasilia, Brasília, DF, Brasil.

E-mail: renatoarthur@gmail.com

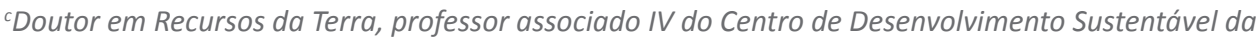
Universidade de Brasília, Brasília, DF, Brasil.

E-mail: jaldrummond@uol.com.br

doi:10.18472/SustDeb.v10n3.2019.24406

Received: 30/04/2019

Accepted: 25/09/2019

ARTICLE-DOSSIER

\begin{abstract}
Water related conflicts have been expanding around the world, especially in areas that experience rapid changes in land use and occupation. The microregion of Ceres (Goiás) has gone through an accelerated process of sugar cane cultivation and processing in recent years and water scarcity problems have emerged. This work seeks to understand potential environmental conflicts related to water resources in the Ceres microregion by evaluating the manners, the intensity and the spatial distribution of water consumption in different basins of the microregion. It analyzed secondary data on water demands, sugar and alcohol production, irrigation and applies geostatistical tools. Results suggest that sugar cane crops have a strong impact on water consumption, although this activity is not related to the water deficits in most basins. This suggests that they are not solely responsible for situations of water scarcity or conflicts associated with this scarcity.
\end{abstract}

Keywords: Socio-environmental Conflicts. Water Resources. Geospatial Analysis. Ceres Microregion. 


\section{RESUMO}

Os conflitos pela água vêm se ampliando em todo o mundo, especialmente em áreas que experimentam rápidas transformações no uso e ocupação do solo. A Microrregião de Ceres (Goiás) passou por um acelerado processo de agroindustrialização canavieira nos últimos anos e com isso, percebem-se problemas de escassez hídrica. Este trabalho contribui para a compreensão dos potenciais conflitos socioambientais pelos recursos hídricos na Microrregião de Ceres (Goiás) a partir da avaliação das formas, intensidade e distribuição espacial do consumo de água em diferentes bacias da microrregião. Foram analisados dados de demandas hídricas, balanço hídrico, produção sucroalcooleira, irrigação e outros a partir de ferramentas geoestatísticas. Os resultados apontam para o forte impacto da cultura canavieira sobre o consumo hídrico, embora essa atividade não esteja correlacionada com o déficit hídrico na maior parte das bacias, o que sugere que esta não seja, isoladamente, a atividade responsável por situações de escassez hídrica ou conflitos relacionados ao desabastecimento.

Palavras-Chave: Conflitos Socioambientais. Recursos Hídricos. Análise Geoespacial. Microrregião de Ceres.

\section{INTRODUCTION}

Water consumption for irrigation of agricultural crops has contributed to increase productivity in Brazil's Cerrado biome. At the same time it has increased the risk of episodes of local water scarcity (CAMPOS FILHO, 2010). The reduced availability of water can act as a driver of conflicts by threatening its multiple uses (GALVÃO, BERMANN, 2015).

Conflicts arise from competition between two or more usergroups with divergent interests. Environmental conflict have, additionally, another feature: the dispute around one or more natural resources (LITTLE, 2001; NASCIMENTO, 2001). In this sense, one of the most important natural resources under disputes is water. Conflicts over the use of this resource have been spreading worldwide, culminating even in several geopolitical tensions. According to Porto and Milanez (2009), socioenvironmental conflicts tend to be more intense in countries that export commodities, such as Brazil. According to a Pastoral Land Commission (Comissão Pastoral da Terra, CPT) report, between 2011 and 2016, conflicts over water increased by $150 \%$ in this country (CPT, 2019). In 2009, conflicts over water in Brazil occurred mainly due to the inadequate use of the resource by hydroelectric dams and affected 40,335 families. By 2018, this number increased to 73,693 households, for a variety of reasons, from community ownership of the resource to pollution by mining activities (CPT, 2019).

Agroindustrialization led to the incorporation and transformation of resources (land and water) of vast Cerrado areas, previously used sparsely for commercial agriculture. Authors such as Mendonça (2015) assert that other regions that have undergone similar transformations have experienced conflicts around the exploitation and use of land and water.

The Ceres Microregion, located in the center of the state of Goiás, stands out for going through rapid changes in land use over the last 15 years (DUTRA et al., 2013; BARBALHO et al., 2015; FERREIRA, 2016; DELLA GIUSTINA et al., 2018). Usually, this transformation occurs in the dominant Cerrado formations, led by increased water use, especially for agricultural production (CAMPOS FILHO, 2010). Some studies allege that sugarcane culture is responsible for building new landscapes in the Ceres Microregion, leading to novel social dynamics and conflicts, especially with regard to water use, (BRITO et al., 2015; BARBALHO et al., 2015; FERREIRA, 2016). Sugarcane production began in this microregion in 1968, with the installation of the Monteiro de Barros sugar mill and distillery in Goianésia, and expanded with the stimulus of the federal government's National Alcohol Program (Proálcool) in the 1970s. After some crises faced by the sector, the National Agroenergy Plan in Brazil (2006-2011) provided new incentives for sugarcane production, leading to a significant increase of this activity in the Ceres Microregion (OLIVEIRA Jr. et al., 2013; BRITO et al., 2015). 
Parallel to the expansion of sugarcane plantations in the microregion, some municipalities have met with problems of water scarcity. In 2018, the Goiás Sanitation Company - SANEAGO - listed four cities in the microregion among those with the highest risk of water shortage in the state of Goiás for the coming years (SANEAGO, 2018). Media outlets record numerous complaints about water shortages local urban areas. Conflicts over water are materialized by complaints received by the Goiás Agency for Regulation, Control and Inspection of Public Services (AGR) and by various notifications of infringement, embargoes and other acts issued by the District Attorney's Office of Goiás (MPGO) and the State Secretariat of Environment and Development (Semad) (PERES, 2017; MARTINS, 2017). Much of these acts are targeted at the sugarcane sector. In popular perception, supported by some studies, the sugarcane irrigation is the most massive use of water in the region and is thus responsible for the generation of social and environmental conflicts (CASTRO, 2010; DUTRA, 2013; FERREIRA, 2016).

On the other hand, cattle farms are the dominant feature of the rural landscape of the Ceres Microregion. Industrial activity plays a very important role in its economy (OLIVEIRA Jr., 2013), a fact ignored by studies of water demand for the region (SILVA, 2008). In addition, water demands and balance vary considerably between basins (LIMA, 2011). On account of this variability, we need to know in detail the natural characteristics of the basins and the respective water use patterns in order to make better decisions in the regulations of competing uses of water in order to avoid, minimize or resolve conflict situations around their use.

This research aims to contribute to a better understanding of the competing uses of water and their relationship with socioenvironmental conflicts in the Ceres Microregion (GO). The objectives are to evaluate the intensity of water consumption in different basins and to estimate which municipalities face risks of conflicts over the use of water resources, considering the different activities and economic sectors. From that, to suggest means to assess risk of conflicts from geospatial information.

\section{METHODS}

The study region - Microregion of Ceres - is composed by 22 municipalities: Barro Alto, Carmo de Rio Verde, Ceres, Goianésia, Guaraíta, Guarinos, Hidrolina, Ipiranga de Goiás, Itapaci, Itapuranga, Morro Agudo de Goiás, Nova América, Nova Glória, Pilar de Goiás, Rialma, Rianápolis, Rubiataba, Santa Isabel, Santa Rita do Novo Destino, São Luiz do Norte, São Patrício and Uruana. This territory has an area of $1,316,283$ ha. The estimated population in 2018 was 249,632 (IMB, 2019). Compared to Brazil and Goiás, the Microregion has a considerable concentration of GDP in industry and agriculture (OLIVEIRA Jr. et al., 2013).

Estimated water demands made by the National Water Resources Information System (SNIRH) were evaluated, together with spatial data on sugar and alcohol production from the CanaSat project, the National Institute for Space Research (INPE) and the Image Processing and Geoprocessing Laboratory (LAPIG).

Consumptive uses contemplated in the SNIRH planning documents are: urban, rural, industrial, irrigation, livestock and others, which include use in thermoelectric and mining. It is noteworthy that the Pastoral Land Commission records no information about conflicts in the microregion, although the commission maintains the largest database on conflicts in the country. We used data related to production, farms and farm staff from the Mauro Borges Institute (IMB), the 2017 Agricultural Census, the 2010 Population Census, among others. Regarding the information on embargoes, infraction notifications or similar facts, the Goiás Agency for Regulation, Control and Inspection of Public Services (AGR), the Goiás District Attorney's Office and the Goiás State Department of Environment and Development (Semad) were consulted.

Estimated water demands by SNIRH were based on state and federal water use permits issued for industrial activities up to July 2014; animal husbandry demand was estimated based on herd sizes by 
municipality for 2013, according to data from the Brazilian Institute of Geography and Statistics (IBGE); human demand estimated were based on data from the IBGE municipal population estimate for 2013; and demand for irrigation was estimated for the base year 2014 using data from water resources plans, the National Water Agency (ANA) and satellite imagery of central pivots, as well as annual growth rates of the irrigated area. Shapefiles of total and sectoral demands were obtained from the SNIRH database in September 2018. The overlapping spatial data allowed us to evaluate the patterns of crop distribution and the intensity of water flow extracted in the "ottobacias" (hydrographic units that make up a river basin).

For regression analysis, we used the Geographically Weighted Regression and Exploratory Regression tools of Esri ArcMap 10.6.1.9270, which use linear regression to model spatially variable relationships. We evaluated the relation between the flow of water demanded for irrigation (dependent variable) and the area irrigated by central pivots (explanatory variable) and the water balance (dependent variable) with the flow rates (explanatory variables). The significance levels adopted were $p<0.01$.

\section{RESULTS AND DISCUSSION}

The population of the Ceres Microregion is predominantly urban, with $83.3 \%$ of people living in urban areas and $16.7 \%$ in rural areas (IBGE, 2018). From 2008 to 2018 the average annual population growth rate of the Ceres microregion was $0.46 \%$, below the rate for the state of Goiás (1.90\%). Since 2013 the microregion has displayed a downward trend in its population growth rate (IMB, 2019).

In 2017, 11,862 agricultural establishments occupied 1,069,457 ha, or $81.24 \%$ of the microregion's area. The rural landscape is dominated by pastures, predominantly planted, followed by native vegetation and crops (Table 1).

Table 1 | Land use classes of agricultural establishments in the Ceres Microregion, Goiás State, by area and percentage, in hectares.

\begin{tabular}{|c|c|c|}
\hline \multirow{2}{*}{ Land use } & \multicolumn{2}{|c|}{ Area } \\
\cline { 2 - 3 } & Hectares & Percentage \\
\hline PASTURES & 661,759 & $61.88 \%$ \\
\hline NATIVE VEGETATION & 192,868 & $18.03 \%$ \\
\hline TEMPORARY CROPS & 156,814 & $14.66 \%$ \\
\hline PERMANENT CROPS & 19,077 & $1.78 \%$ \\
\hline OTHERS & 38,939 & $3.64 \%$ \\
\hline TOTAL & $1,069.457$ & $100 \%$ \\
\hline
\end{tabular}

Source: IBGE (2018).

Although temporary crops (predominantly sugar cane, soybeans and corn) account for less than $15 \%$ of the microregion's rural landscape, they have increased significantly over the last ten years. Cultivated area in sugarcane in the microregion increased from 84,006 ha in 2007 to 101,340 ha in 2017, an increase of $21 \%$ (Figure 1). Soybean occupied 20,970 ha in 2017 , after increasing its cultivated area by $123 \%$ over the previous ten years (IMB, 2019), along with the 10,850 ha of maize crops and the extensive 661,759 ha pastures, these crops dominated the rural landscape of the microregion in 2017 (IBGE, 2018). 


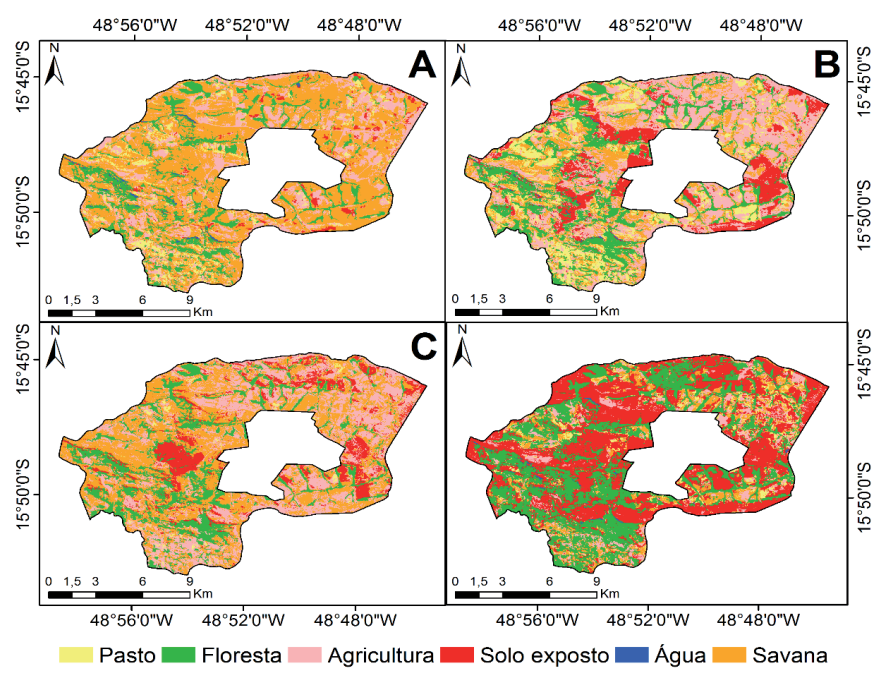

Figure 1 | Annual evolution of sugarcane, corn and soybean acreage in the Ceres Microregion, State of Goiás, from 2000 to 2017, in hectares.

Fonte: IMB (2019).

Sugarcane planting increased 63\% in area from 2006 to 2017, while soybean expanded its planted area by $84 \%$ during the same period. Even so, sugarcane representativeness (65\%) is higher than that of other temporary crops in the Ceres Microregion (IBGE, 2018). On the other hand, sugarcane acreage showed an upward trend until 2011, when it stabilized at 105,000 hectares, while soybean continues to expand its share of the region's planted area.

Regarding the spatial characteristics of water uses, we evaluated the intensity of water withdrawal flows in the microregion. The data are presented by ottobacias, which are the minimum units for hydrographic planning in the country. Figure 2 shows the intensity of withdrawal flows in the 309 ottobacias of the Ceres Microregion.

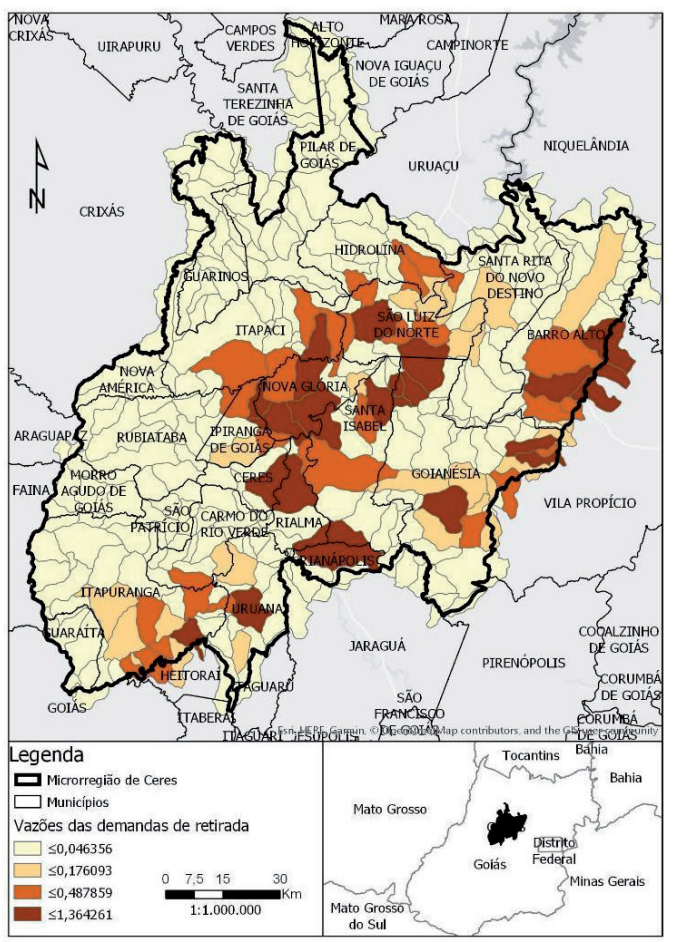

Figure 2 | Intensity of water withdrawal flows in the Ceres Microregion, Goiás. Source: Sistema Nacional de Informações sobre Recursos Hídricos (SNIRH, 2019). 
Intakes range from 0.00033 to $1.36 \mathrm{~m} / \mathrm{s}$ per basin. The most intensively used basins, based on the value of the total withdrawal flow, are distributed mostly in the municipalities of Barro Alto, Nova Glória, São Luiz do Norte, Santa Isabel, Goianésia, Ceres, Rialma, Rianápolis and Uruana. Most of the heavily used basins are associated with the Rio das Almas river basin (64993 - Foz do Rio S. Patrício / Rio do Peixe; 64995 - Foz do Rio do Peixe / Rio Verde), the eastern basin of the São Patrício River and the Patos River, on the eastern part of the microregion.

Until March 2019, 91 water use licenses issued by the State of Goiás were in force for the Ceres Microregion (SNIRH, 2019). They authorize the removal of up to $4.46 \mathrm{~m} 3 / \mathrm{s}$ of water from underground and surface water bodies. Of this total, 65 licenses were granted for irrigation $(3.22 \mathrm{~m} 3 / \mathrm{s}) ; 12$ for urban or rural supply $(0.69 \mathrm{~m} / \mathrm{s}) ; 11$ for industries $(0.51 \mathrm{m3} / \mathrm{s})$ and the rest for aquaculture and other uses. These figures represent, in terms of flow, $72.19 \%$ for irrigation, $15.47 \%$ for urban or rural supply; $11.46 \%$ for industries and $0.88 \%$ for other uses.

However, this reality varies and thus some basins are much more overworked than others, with different demands. Water demand data between 1970 and 2018, based on withdrawal flow for different uses, also varied greatly over time (Figure 3 ).

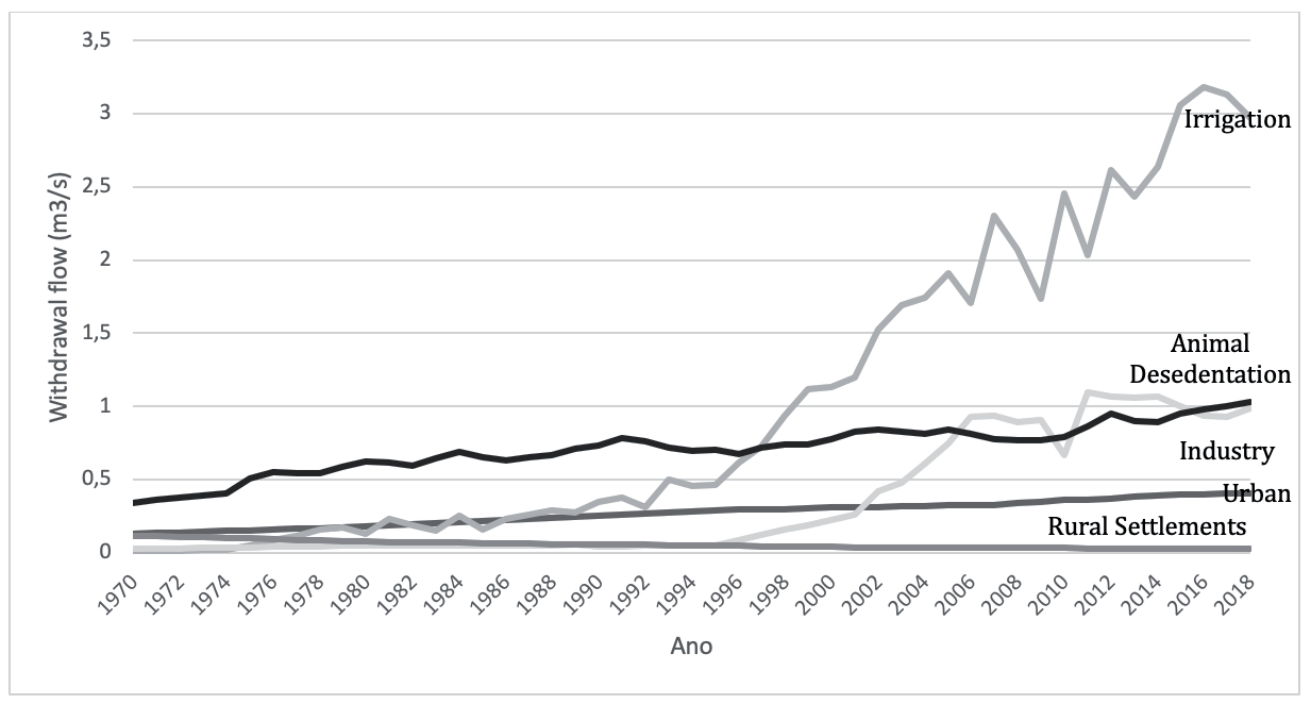

Figure 3 | Main sectoral water demands in the Ceres Microregion, Goiás State, between 1970 and 2018, measured in water withdrawal flow rates $(\mathrm{m} 3 / \mathrm{s})$.

Source: ANA (2019).

Water withdrawal by rural settlements has declined in absolute terms, but without changing significantly over almost 50 years. On the other hand, in urban areas there is an almost continuous growth. This can be explained by the change in the distribution of the region's population - the urban population of the Ceres Microregion increased from 50\% in 1980 to $67 \%$ in 1991, 78\% in 2000 and now stands at $83 \%$ (IBGE, 2010).

In the mid-1990s, there was a marked increase in industrial consumption, which maintained a fairly stable level since 2006. This increase can be attributed to the expansion of the sugar and alcohol sector (FERREIRA, 2016). Most of this consumption is currently linked to sugarcane mills (70\%), followed by the meat and dairy industries (19\%), mining (6\%) and other industries (5\%) (SNIRH, 2018).

Industrial consumption levels competes, in absolute numbers, with the flows destined for animal husbandry, an activity that grew moderately and continuously during the period under analysis. The cattle herd fluctuated between 960 thousand and 1.2 million head (IMB, 2019). 
However, water withdrawal for irrigation, equivalent to the flow intended for urban areas between the late 1970s and early 1990s, showed a significant growth trend from 1995 onwards, with oscillations between 2005 and 2013. During this period of Brazil's high financial instability, the area planted with sugarcane fluctuated a lot, until it grew again in 2015 and currently it shows a slight decrease (FERREIRA, 2016).

For an exploratory spatial analysis related to the types of water use and the intensity of total water demand, we calculated the correlation coefficients of the sectoral flow values in relation to the total demand. The only sector that showed a significant correlation $(r=0.997, n=309)$ was irrigation. This may suggest that the basins in which there is a stronger presence of irrigation also display a greater total demand for water. The other uses showed weakly significant correlation values, ranging from $r=$ 0.137 for rural flow, $r=0.210$ for industrial, $r=0.149$ for urban and $r=0.11$ for animal husbandry. Basin areas were also analyzed and showed no significant correlation with total demand $(r=0.26, n=309)$.

Among the ten basins with the highest demands for water, irrigation is the predominant use, ranging from $97.98 \%$ to $99.82 \%$, except for the ottobacia 6482311 , located in the municipality of Barro Alto, and in the Patos River basin, where water demand is divided between irrigation (73.21\%) and industry (26.44\%), the latter being destined mainly for mining industries (Table 2).

Table 2 | Flow data, in $\mathrm{m}^{3} / \mathrm{s}$.year ${ }^{-1}$, and percentage of the contribution of the ten largest total demands for consumptive water use, by sectoral demands, by ottobacia and municipalities, in the Ceres Microregion, Goiás state.

\begin{tabular}{|c|c|c|c|c|c|c|c|}
\hline Ottobacia & Municipalities & $\begin{array}{c}\text { Total } \\
(\mathrm{m} 3 / \mathrm{s})\end{array}$ & Urban & Irrigation & Rural & Animal & Industry \\
\hline 64951 & $\begin{array}{c}\text { Nova Glória, Rialma } \\
\text { e Ipiranga de Goiás }\end{array}$ & 1.36426076 & $1,04 \%$ & $98.79 \%$ & $0.01 \%$ & $0.15 \%$ & - \\
\hline 648251 & Goianésia & 1.32136693 & - & $99.95 \%$ & $0.00 \%$ & $0.05 \%$ & - \\
\hline 649912 & Rianápolis, Rialma e Santa Isabel & 0.95211993 & $1,02 \%$ & $97.98 \%$ & $0.05 \%$ & $0.96 \%$ & - \\
\hline 648213 & Barro Alto & 0.91348924 & - & $99.83 \%$ & $0.01 \%$ & $0.16 \%$ & - \\
\hline 6482311 & Barro Alto & 0.83970716 & - & $73.21 \%$ & $0.01 \%$ & $0.34 \%$ & $26.44 \%$ \\
\hline 6491783 & Goianésia & 0.75678463 & - & $99.82 \%$ & $0.00 \%$ & $0.17 \%$ & - \\
\hline 649252 & Nova Glória e Ipiranga de Goiás & 0.71752573 & - & $99.73 \%$ & $0.02 \%$ & $0.25 \%$ & - \\
\hline 649172 & São Luiz do Norte & 0.71642803 & $0,87 \%$ & $98.82 \%$ & $0.01 \%$ & $0.29 \%$ & - \\
\hline 649837 & Itapuranga & 0.7081769 & - & $99.55 \%$ & $0.01 \%$ & $0.44 \%$ & - \\
\hline 649832 & Uruana & 0.6348115 & - & $99.11 \%$ & $0.06 \%$ & $0.83 \%$ & - \\
\hline
\end{tabular}

Source: SNIRH (2018).

In the ten most intensively used watersheds, the flow in water use for urban and rural sectors, as well as for animal husbandry use, hardly exceeds $1 \%$ of total demand. This is the case of ottobacia 64951 , which supplies the municipal headquarters of Nova Glória; and ottobacia 649912, which supplies the municipal seat of Rianápolis. Some ottobacias supply two or more municipal seats, such as 64955 , which supplies Rialma and Ceres, with a destination of $13.32 \%$ of its total flow $\left(0.0979 \mathrm{~m}^{3} / \mathrm{s}\right)$ for urban use.

Even in less intensively used basins urban supply competes with irrigation and industry and may generate greater conflict during times of scarcity. These are the cases of the 6482643 basins (total withdrawal $=0.5454 \mathrm{~m}^{3} / \mathrm{s} ; 17 \%$ urban, $79 \%$ industrial and $4 \%$ others), 6482642 (total withdrawal = $0.0806 \mathrm{~m}^{3} / \mathrm{s} ; 17 \%$ urban, $81 \% 649423$ (total withdrawal $=0.0 .593 \mathrm{~m}^{3} / \mathrm{s} ; 15 \%$ urban, $71 \%$ industrial and $14 \%$ other), 649523 (total withdrawal $=0.0354 \mathrm{~m} 3 / \mathrm{s} ; 11 \%$ urban, $64 \%$ irrigation and $25 \%$ others) which supply the municipal seats of Goianésia and Ipiranga de Goiás. They were classified by the Goiás 
Sanitation Company among the cities with the highest risk of water shortage in the state of Goiás for the next years (SANEAGO, 2018).

An exceptional case of high proportion in urban flow is the municipality of Hidrolina, in the São Patrício river valley region. It amounts to $60.42 \%$ of the total flow. This is explained by the low participation of the agricultural and industrial sectors in the local economy, which is based on commerce and animal husbandry, whose contribution to the consumptive use of water reaches $38.59 \%$. Even though, compared to the others, this municipality does not display an intensive use of water. Hidrolina is among the cities with the highest risk of water shortage in the state of Goiás (SANEAGO, 2018).

Only the ottobacias 694963, located in the west of the municipality of Guarinos, in the Caiamar river basin, and 69487, north of the municipality of Pilar de Goiás, in the Formiga river basin, have a significant proportion of water funneled to industrial activity, reaching $95.78 \%$ and $78.96 \%$ of total demand, respectively. Nevertheless, both basins have comparatively low total withdrawal flows $\left(0.046 \mathrm{~m}^{3} / \mathrm{s}\right.$ and 0.036 $\mathrm{m}^{3} / \mathrm{s}$, respectively). This does not constitute a scenario of a potential competition for water resources.

Correlation analysis shows that irrigation is responsible for a significantly higher consumptive demand than other uses. This means that it impacts total demand more significantly than other activities, increasing total water withdrawal. As noted in Table 2, most of these basins are preferentially dedicated to irrigation, without offering competition with other uses and thus do not enhance conflicts between the water supplied sectors.

In order to better understand the information related to demands for irrigation water, we also checked which irrigation equipment is used and which crops require higher levels of irrigation.

Besides being the dominant crop in the region, sugarcane is the one that demands the highest level of irrigation. Water requirements of sugarcane is around $1,780 \mathrm{~mm} /$ cycle and can vary between 1,000 and 2,000 $\mathrm{mm} /$ cycle. This is why it is considered a crop with a high demand for water. Soybean, the second largest crop planted in the microregion, has a water demand between 450 and $850 \mathrm{~mm}$ and maize demands vary from 380 to $550 \mathrm{~mm}$ (CARVALHO et al., 2013). Also corroborating the pressure of sugarcane on water is that of the total of 60,486 ha irrigated in the microregion, $81.38 \%$ are destined only for this crop (SNIRH, 2018). On the other hand, Silva et al. (2008) state that the Ceres Microregion displays a low irrigation demand specifically for its sugarcane crops.

Concerning the use of pivots in the different microregion crops, earlier studies (CASTRO, 2010; DUTRA, 2013; FERREIRA, 2016) indicate that most of them are intended for sugarcane cultivation and that this crop is a strong candidate to generate social and environmental conflicts regarding water use.

Of the 106 ottobacias that display irrigation uses, 48 (45\%) supply 238 pivots, which irrigate a total area of 10,446 ha, about $0.8 \%$ of the microregion area (ANA \& Embrapa, 2019). Based on a density map generated by the center point of the pivots, we found that there is no overlap of the areas with the most numerous pivots with the basins displaying the highest intensity of use. There are basins whose water is intensively used without the presence of pivots, as is the case of ottobacias 649252 (total demand $\left.=0.71 \mathrm{~m}^{3} / \mathrm{s}\right), 64951\left(1.36 \mathrm{~m}^{3} / \mathrm{s}\right), 648213\left(0.91 \mathrm{~m}^{3} / \mathrm{s}\right)$ and $649837\left(0.70 \mathrm{~m}^{3} / \mathrm{s}\right)$. Other basins, such as 649145 (total demand $\left.=0.10 \mathrm{~m}^{3} / \mathrm{s}\right), 6491711\left(0.07 \mathrm{~m}^{3} / \mathrm{s}\right.$ ) and $649141\left(0.04 \mathrm{~m}^{3} / \mathrm{s}\right)$, have many pivots that do not result in high demand for water.

Additionally, when analyzing the relationship between center pivots and irrigation withdrawal flows, we obtained an $r^{2}=0.3828$, which shows that there is no significant correlation between the variables. Thus, it is possible to infer that central pivots, present in $8.2 \%(n=49)$ of the agricultural establishments that use irrigation in the microregion, are not the main vectors for high water demand. This shows that not all of the intensive demand for irrigation water feeds central pivots. This corroborates the data presented by Pereira Jr. (2017), who states that pivots are not a major factor in the pressure on water supply. 
This information suggests that other irrigation methods and other irrigated crops may be responsible for the increased pressure on water demand in the region. We produced a visual depiction of the overlap of the distribution of the three main temporary crops of the microregion with the most intensively used ottobacias for irrigation (Figure 4).

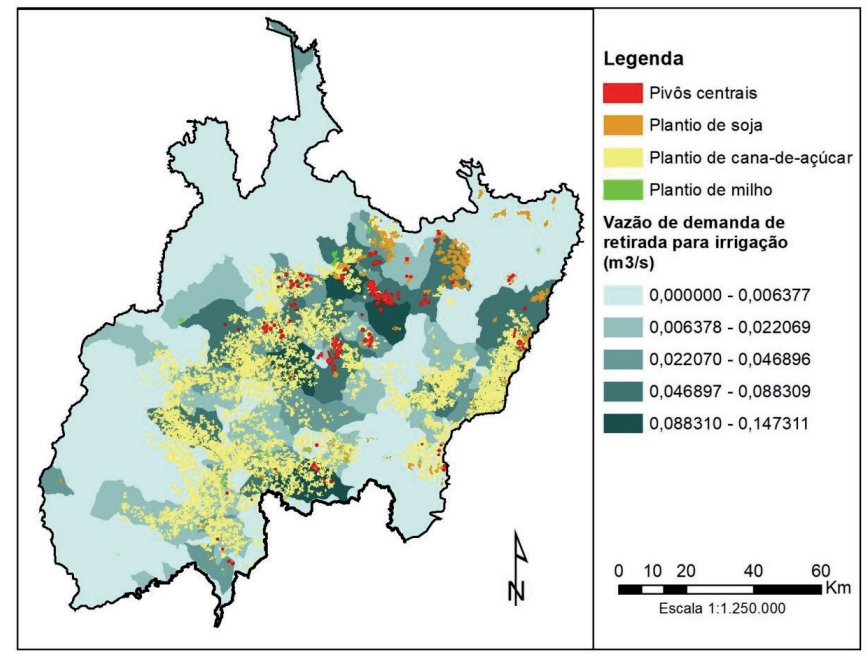

Figure 4 - Overlap of the central pivots, soybean, sugarcane and corn plantations with the flow rates of irrigation withdrawal demands $(\mathrm{m} 3 / \mathrm{s})$ in the Ceres Microregion, Goiás State.

Source: Lapig, 2019; IBGE, 2017.

Although the overlap demonstrates that temporary crops are distributed over basins that have irrigation demands greater than $0.0063 \mathrm{~m}^{3} / \mathrm{s}$, this distribution does not show correlation with basins with higher irrigation intensity (flow greater than $0.0883 \mathrm{~m} / \mathrm{s}$ ). Nevertheless, the grants in these last basins were for sugarcane agro-industries such as CRV Industrial in Santa Isabel, Jalles Machado in São Luiz do Norte and Agro-Rub Farming in Nova Glória, even though they were not used for temporary crops at the time of the mapping, in 2016. This information suggests the existence of a significant water demand for industrial sugarcane processing, which consumes, on average, $21 \mathrm{~m}^{3} /$ ton (ELIA NETO, 2005).

We assessed also the quantitative water balance, which represents the difference between water supply and demand per basin. The water balance data obtained by SNIRH (2019) were compared with the watershed discharge data for different uses: irrigation, urban supply and industry. Figure 5 illustrates this overlap.

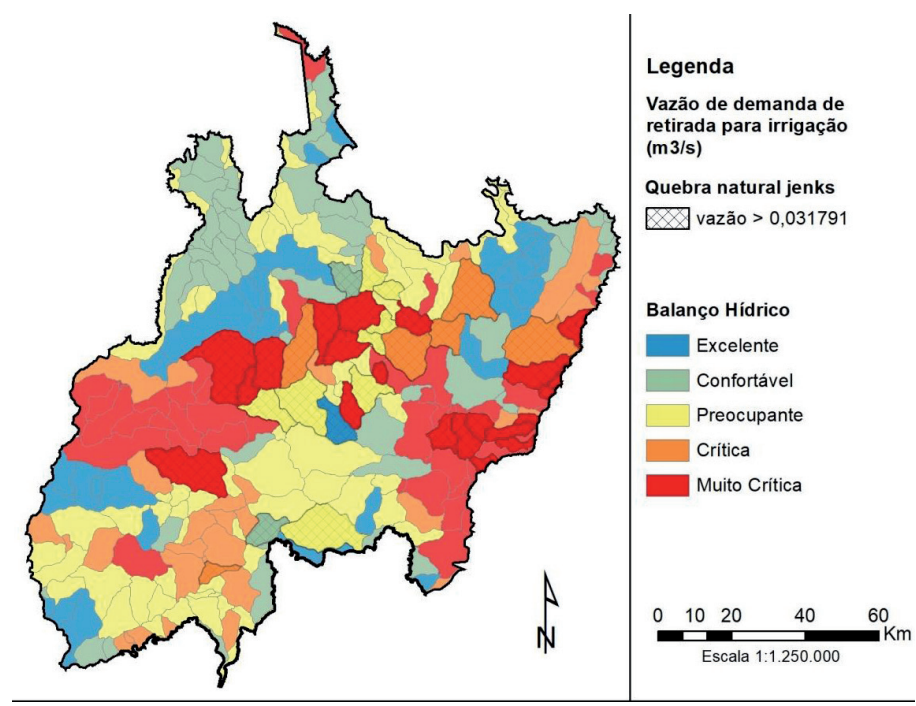

Figure 5 | Overlap of the largest flow rates of withdrawal demand for irrigation, referring to the upper class of natural break Jenks with the water balance of the watersheds in the Ceres Microregion, Goiás State.

Source: Sistema Nacional de Informações em Recursos Hídricos (SNIRH, 2019). 
Regression analysis shows that there is no significant correlation $(r 2=0.001)$ between water balance (dependent variable) and withdrawal flow for urban supply; it also has no correlation $(r 2=0.009)$ in the balance with the withdrawal flow for industrial use, as well as the water balance with the withdrawal for irrigation $(r 2=0.163)$. Thus, we found that the water balance has not been affected by the uses of specific sectors.

Regarding systematic records of socioenvironmental conflicts over water, they do not exist for the Ceres Microregion between 2009 and 2018 (CPT, 2019). However, we found records of complaints and warning notices from the District Attorney's Office; notifications of infraction and embargoes issued by the State Department of Environment and Development of Goiás (Semad); and news stories in local newspapers reporting water scarcity problems faced by urban populations in the microregion, as well as irregularities in water catchment, whether by agricultural enterprises, industries and municipal governments.

In order to mitigate problems of water scarcity, the municipality of Ceres issued Normative Resolution No. 0110/2017, containing water-rationing measures. The municipality also adopted a "water rationing plan", aimed specifically at the urban population.

Documents issued by the Goiás' Agency for Regulation, Control and Inspection of Public Services (AGR) include several reports of water shortages in the municipalities of Rialma, Barro Alto, Ceres, Rialma and São Luís do Norte. These municipalities are among the largest consumers of water, according to the data presented in Figure 2 and Table 2. Nevertheless, most of these occurrences resulted from operational problems, such as clogging, pump malfunction, lack of electricity for pumping, among others. None of the 2017 and 2018 occurrences were related to water scarcity.

\section{CONCLUSIONS}

From our analysis, we concluded that water withdrawal varies considerably among the basins of the Ceres Microregion. This is due both to the intrinsic characteristics of available basin flow and to water use derived from different modalities of land use. In general, the highest withdrawal intensity is correlated with irrigation activity and especially with sugarcane cultivation, both in agricultural production and in industrial processing. The grants found for the basins with highest water demands refer to sugar and alcohol plants - not to crop irrigation. Despite the frequent use of central pivots in sugarcane cultivation, impact of irrigation by central pivots is small in relation to the total water consumed for sugarcane. The spatial distribution of pivots is not related to the most intensively used basins.

The literature states that sugarcane cultivation in the studied microregion is one of the main factors for the occurrence of social and environmental conflicts over water resources. However, existing systematic records provide no data on water-related conflicts for the region even though several legal and administrative acts have been issued due to misuse or overuse of water by some sugarcane companies.

Despite its small spatial participation in the studied territory, the importance of sugarcane cultivation in water consumption was confirmed in our study. This includes water used in industrial processing. This exempts central pivots from the leading role in water demand. We also consider water consumed by the other temporary crops (soybean and corn) and by industrial activities. Although livestock predominates in the landscape of the microregion, water consumption by this sector does not significantly impact the total water demand.

In some basins a high percentage of water demand is for urban consumption, especially in the cases of the municipal seats of Hidrolina, Goianésia and Ipiranga de Goiás, the last two classified as having a high risk of shortage. In these basins there is competition between urban and industrial uses, although total demand is low. On the other hand, the seats of the municipalities of Barro Alto, Ceres, Rialma and São Luís do Norte have high urban demand but the participation of irrigation is high. These municipalities are not classified as critically prone to water scarcity. Even though the lack of water records in these 
urban centers in recent years has coincided with the most demanded basins for irrigation, we found that most of the problems were operational and thus they were not related to water scarcity.

This research reinforces the importance of using geospatial tools to corroborate or complement exploratory studies of the correlation between production data, water demand and water use. Our research illustrates a methodological path that can be replicated in other basins or other spatial contexts, using data on water balance, land use and land cover, and other grants to plan or regulate local uses from water. Decision-making needs to consider local specificities and focus on competing uses of water.

\section{ACKNOWLEDGEMENTS}

We thank the CAPES Foundation for funding the National Program for Academic Cooperation - PROCAD project entitled "New Frontiers in the West: Relationship between Society and Nature in the Ceres Microregion in Goiás (1940-2013)".

\section{REFERENCES}

ANA - Agência Nacional de Águas. Manual de Usos Consuntivos da Água no Brasil. Brasília: ANA, 2019. Disponível em: <http://snirh.gov.br/usos-da-agua/>. Acesso em: 20 de abril de 2019.

ANA - Agência Nacional de Águas; Embrapa Milho e Sorgo. Levantamento da agricultura irrigada por pivôs centrais no Brasil. - 2. ed. - Brasília: ANA, 2019.

GUIMARAES, D. P.; LANDAU, E. C. Levantamento da agricultura irrigada por pivôs centrais no Brasil em 2013. Embrapa Milho e Sorgo-Boletim de Pesquisa e Desenvolvimento (INFOTECA-E), 2014.

BRITO, Gustavo Henrique Mendes et al. DETERMINAÇÃo DA ÁREA CULTIVADA COM CANA-DE-AÇÚCAR NA MICRORREGIÃO DE CERES (GO) ATRAVÉS DE IMAGENS LANDSAT TM. Cientific@-Multidisciplinary Journal, v. 2, n. 1, p. 71-83, 2015.

CAMPOS FILHO, Romualdo Pessoa. Um olhar geopolítico sobre a água no cerrado: apontamentos para uma preocupação estratégica. Cerrados: perspectivas e olhares, p. 93, 2010.

CASTILHO, Denis. A Colônia Agrícola Nacional de Goiás (CANG) e a formação de Ceres-GO-Brasil. Élisée-Revista de Geografia da UEG, v. 1, n. 01, p. 117-139, 2012.

CASTRO, Selma Simões de et al. A expansão da cana-de-açúcar no cerrado e no estado de Goiás: elementos para uma análise espacial do processo. 2010.

CARVALHO, Ivan Ricardo et al. Demanda hídrica das culturas de interesse agronômico. Enciclopédia biosfera, Centro Científico Conhecer-Goiânia, v. 9, n. 17, p. 969, 2013.

COMISSÃO PASTORAL DA TERRA, 2019. Conflitos pela Água 2019. Disponível em: <https://www.cptnacional.org. br/component/jdownloads/category/6-conflitos-pela-agua> Acesso em: 28 de março de 2019.

DA SILVA, Fernando A. Macena et al. Avaliação da oferta e da demanda hídrica para o cultivo de cana-de-açúcar no Estado de Goiás. 2008.

DAS CHAGAS, Arley Henrique Borges et al. Gestão das Águas no Estado de Goiás: Perspectivas para a participação da Universidade na instalação e atuação do Comitê das Bacias Hidrográficas do Rio das Almas e Afluentes 
Goianos do Rio Maranhão. Fronteiras: Journal of Social, Technological and Environmental Science, v. 6, n. 2, p. 147-166, 2017.

DUTRA, Sandro et al. A Expansão Sucroalcooleira e a Devastação Ambiental nas Matas de São Patrício, Microrregião de Ceres, Goiás. História, histórias, v. 1, n. 2, p. 230-247, 2013.

ELIA NETO, A. Captação e uso de água no processamento da cana-de-açúcar. In: MACEDO, I.C. et al., A energia da cana-de-açúcar: doze estudos sobre a agroindústria da cana-de-açúcar no Brasil e a sua sustentabilidade. São Paulo: ÚNICA, 2005. P 104 a 110.

FERREIRA, Lara Cristine Gomes. As paisagens regionais na Microrregião de Ceres (GO): das colônias agrícolas nacionais ao agronegócio sucroenergético. 2016. 296 f., il. Tese (Doutorado em Geografia) — Universidade de Brasília, Brasília, 2016.

FERREIRA, Lara Cristine Gomes; DE DEUS, João Batista. O uso do território e as redes na microrregião Ceres (GO): o caso das agroindústrias sucroalcooleiras. Boletim Goiano de Geografia, v. 30, n. 2, p. 67-80, 2010.

GALVÃO, Jucilene; BERMANN, Célio. Crise hídrica e energia: conflitos no uso múltiplo das águas. estudos avançados, v. 29, n. 84, p. 43-68, 2015.

GIUSTINA, C. C., SILVA, S., \& MARTINS, E. (2018). Geographic reconstruction of a Central-West Brazilian landscape devastated during the first half of the 20th century: Mato Grosso de Goiás. Sustentabilidade Em Debate, 9(3), 44 - 63. https://doi.org/10.18472/SustDeb.v9n3.2018.18588

GONÇALVES DA SILVA BARBALHO, M., DUTRA e SILVA, S., \& CHRISTIAN DELLA GIUSTINA, C. C. D. G. (2015). Avaliação Temporal do Perfil da Vegetação da Microrregião de Ceres Através do Uso de Métricas de Paisagem. Boletim Goiano De Geografia, 35(3), 472-487. https://doi.org/10.5216/bgg.v35i3.38837

IBGE, 2010. Censo Demográfico 2010. Rio de Janeiro: IBGE, 2010a. Disponível em: <http://censo2010.ibge.gov. br> Acesso em 10 de março de 2019.

IBGE, 2019. Produção Agrícola Municipal. Disponível em <https://sidra.ibge.gov.br/tabela/1612> Acesso em 10 de março de 2019.

IMB - Instituto Mauro Borges de Estatísticas e Estudos Socioeconômicos, 2019. Bancos de Dados Estatísticos do Estado de Goiás. Disponível em: http://www.imb.go.gov.br/bde/; Acesso em: 20 de abril de 2019.

LIMA, Jorge Enoch Furquim Werneck. Situação e perspectivas sobre as águas do cerrado. Ciência e Cultura, v. 63, n. 3, p. 27-29, 2011.

LITTLE, Paul E.. Os Conflitos Socioambientais: um Campo de Estudo e de Ação Política.(Org.) BURSZTYN, M. A Difícil Sustentabilidade: Política energética e conflitos ambientais. Rio de Janeiro: Ed. Garamond Ltda, p. 107-122, 2001.

MARTINS, ATAALBA. As Ações Civis Públicas Ambientais na Comarca de Ceres-GO: a aplicabilidade da Lei $n$ o 7.347/85 pelo Judiciário por meio da provocação do Ministério Público do Estado de Goiás e a judicialização da preservação do meio ambiente. Dissertação de Mestrado (Mestrado em Sociedade, Tecnologia e Meio Ambiente), Centro Universitário Anápolis. 2017.

MENDONÇA, Marcelo Rodrigues. As Transformações Espaciais no Campo e os Conflitos pelo Acesso a Terra e a Água: As Novas Territorialidades do Agrohidronegócio em Goiás. PEGADA-A Revista da Geografia do Trabalho, v. 16, 2015. 
NASCIMENTO, Elimar Pinheiro do. Os conflitos na sociedade moderna: uma introdução conceitual. Marcel Bursztyn, A difícil sustentabilidade: política energética e conflitos ambientais, Garamond, Río de Janeiro, 2001.

OLIVEIRA Jr et al. 2013. Estudos Microrregionais. Estudos e Pesquisas Econômicas, Sociais e Educacionais sobre as Microrregiões do Estado de Goiás - Microrregião de Ceres. Goiânia: Instituto Federal de Goiás, 2013.

PEREIRA JÚNIOR, Lindolfo Caetano et al. O uso da água em Goiás, potencialidade, demanda para irrigação por pivôs centrais e perspectivas. Dissertação de Mestrado (Mestrado em Ciências Ambientais), Universidade Federal de Goiás, 2017.

PERES, A. L. G. P. Rio das Almas: Políticas Públicas para garantir a segurança hídrica do município de Ceres. Dissertação de Mestrado (Mestrado em Sociedade, Tecnologia e Meio Ambiente), Centro Universitário Anápolis. 2017.

PORTO, M. F. MILANEZ, B. Eixos de desenvolvimento econômico e geração de conflitos socioambientais no Brasil: desafios para a sustentabilidade e a justiça ambiental. Ciência \& Saúde Coletiva 2009, 14 (6).

SANEAGO. Relatório de Sustentabilidade. 2018. Disponível em < https://www.saneago.com.br/2016/lai/rel_ sustentabilidade_2018.pdf > Acesso em 24 de abril de 2019.

SAUER, Sérgio; PIETRAFESA, José Paulo. Cana-de-açúcar, financiamento público e produção de alimentos no cerrado. 2012.

SILVA, F. A. M., MÜLLER, A. G., LIMA, J. E. W., \& MEDRADO, E. (2008). Avaliação da oferta e da demanda hídrica para o cultivo de cana-de-açúcar no Estado de Goiás. Anais do IX Simpósio Nacional do Cerrado, Parlamundi, Brasília, 2018. Disponível em < http://simposio.cpac.embrapa.br/simposio\%20em\%20pc210\%20(Pc210)/ trabalhos_pdf/00825_trab1_ap.pdf> Acesso em 10 de abril de 2019.

VICTORINO, Valério Igor P. Monopólio, conflito e participação na gestão dos recursos hídricos. Ambient. Soc., Campinas, v.6, n. 2, p. 47-62, dez. 2003. Acesso em: 28 de novembro de 2017. 